\title{
ORAL HYGIENE BURUK PASIEN RAWAT INAP TIDAK BERKAITAN DENGAN PERTUMBUHAN ORAL CANDIDIASIS
}

Addina Aimana Sabila*., Ade Ismail A.K ${ }^{\star *}$, Rochman Mujayanto ${ }^{\star * *}$

Keywords:

Oral Hygiene,

Oral Candidiasis

\section{ABSTRACT}

Background: Nosocomial infections can develop in the oral cavity due to poor oral hygiene. Oral Candidiasis is one of the most frequent nosocomial infection in oral cavity. The objective of this study is to describe the oral hygiene and oral candidiasis in hospitalized patients.

Method: This analitical observational study used cross sectional design. Subject of the study were 74 adult patients aged $20-65$ who are hospitalized at the Sultan Agung Islamic Hospital Semarang. Oral hygiene assessed from the presence of debris and calculus on the tooth surface using Simplified Oral Hygiene Index (OHIS) that were grouped in three categories (good, moderate, bad). Oral candidiasis diagnosed through clinical examination and swab procedure of suspicious lesions, and identified the presence of its spores and hyphae under a microscope observation. Kendal Tau test is used to analyze the correlation between oral hygiene with oral candidiasis.

Results: Results showed patients with oral candidiasis in the poor and moderate oral hygiene were $29.7 \%$ and $1.4 \%$, whereas patients without oral candidiasis in the poor and moderate oral hygiene were $60.8 \%$ and $8.1 \%$. Kendall Tau correlation test results $p$ value of 0.235 ( $p>0.05$ ).

Conclusion: Conclusion of this study showed there is no association between oral hygiene with oral candidiasis.

\section{PENDAHULUAN}

Oral Candidiasis merupakan infeksi pada mukosa mulut yang disebabkan Candida spp. yang menjadi patogen. ${ }^{1}$ Candida spp. merupakan salah satu infeksi nosokomial yang paling sering muncul di seluruh dunia dengan angka morbiditas, mortalitas yang tinggi. Candida spp. adalah anggota flora normal terutama saluran pencernaan, selaput mukosa rongga mulut, vagina, uretra, kulit. Ditempattempat ini jamur dapat menjadi dominan dan menyebabkan keadaan-keadaan patologik ketika daya tahan tubuh menurun baik secara lokal maupun sistemik. ${ }^{2}$

Perawatan kebersihan mulut merupakan bagian penting dari pengobatan untuk pasien rawat inap. Pasien rawat inap merupakan awal dari penurunan fungsional dan peningkatan ketergantungan yang dapat menyebabkan seseorang individu membutuhkan perawatan jangka panjang. ${ }^{3}$ Kebersihan mulut yang buruk pada pasien rawat inap meningkatkan risiko infeksi nosokomial berupa gingivitis, plak, dan mukositis. $^{4}$

\section{METODE PENELITIAN}

Jenis penelitian ini adalah penelitian observasional analitik dengan rancangan cross sectional. Subjek penelitian pasien rawat inap di Rumah Sakit Islam Sultan Agung Semarang

*Program Pendidikan Profesi Dokter Gigi Fakultas Kedokteran Gigi Universitas Islam Sultan Agung, **Departemen Periodonsi Fakultas Kedokteran Gigi Universitas Islam Sultan Agung, ${ }^{* *}$ Departemen Oral Medicine Fakultas Kedokteran Gigi Universitas Islam Sultan Agung Korespondensi: addina_sabila@yahoo.com 
Tabel 1

Karakteristik pasien rawat inap di Rumah Sakit Islam Sultan Agung Semarang

\begin{tabular}{llll}
\hline & & Jumlah & Persen \\
\hline Jenis Kelamin & Laki-laki & 53 & 71,6 \\
& Perempuan & 21 & 28,4 \\
Kelompok umur & $\leq 45$ tahun & 38 & 51,4 \\
& $>45$ tahun & 36 & 48,6 \\
Kriteria OHI-S & Buruk & 67 & 90,5 \\
& Sedang & 7 & 9,5 \\
& Baik & 0 & 0,0 \\
Oral candidiasis & Positif & 23 & 31,1 \\
& Negatif & 51 & 68,9 \\
\hline
\end{tabular}

Tabel 2

Karakteristik pasien rawat inap di Rumah Sakit Islam Sultan Agung Semarang berdasarkan ada tidaknya oral candidiasis

\begin{tabular}{llllll}
\hline \multirow{2}{*}{ Karakteristik } & & \multicolumn{2}{l}{ Oral candidiasis } & \multirow{2}{*}{ Total } & \multirow{2}{*}{ Sig (p) } \\
\cline { 3 - 4 } & & Positif & Negatif & & \\
\hline Jenis & Laki-laki & $14(18,9 \%)$ & $39(52,7 \%)$ & $53(71,6 \%)$ & 0,168 \\
Kelamin & Perempuan & $9(12,2 \%)$ & $12(16,2 \%)$ & $21(28,4 \%)$ & \\
Kelompok & $\leq 45$ tahun & $10(13,5 \%)$ & $28(37,8 \%)$ & $38(51,4 \%)$ & 0,363 \\
umur & $>45$ tahun & $13(17,6 \%)$ & $23(31,1 \%)$ & $36(48,6 \%)$ & \\
Kriteria OHI- & Buruk & $22(29,7 \%)$ & $45(60,8 \%)$ & $67(90,5 \%)$ & \multirow{2}{*}{0,235} \\
S & Sedang & $1(1,4 \%)$ & $6(8,1 \%)$ & $7(9,5 \%)$ & \\
\hline
\end{tabular}

yang lebih dari 3 hari. Oral hygiene dinilai dari keberadaan debris dan kalkulus pada permukaan gigi menggunakan Oral Hygiene Index Simplified (OHIS) dikelompokkan dalam tiga kategori (baik, sedang, buruk). Candidiasis oral didiagnosis dengan swab mukosa mulut dan diamati secara mikroskopis untuk melihat hifa dan spora. Uji Kendal Tau digunakan untuk menganalisis keterkaitan oral hygiene dengan oral candidiasis.

Hasil analisis data penelitian ditunjukkan sebagai pada tabel 1. Tabel 1 menunjukkan bahwa sampel penelitian ini sebagian besar adalah laki-laki $(71,6 \%)$, berumur antara 22 - 33 tahun dan ketika umur dikelompokkan sebagai $\leq 45$ dan 45 tahun proporsi pasien berdasarkan kelompok umur adalah relatif sama yaitu $51,4 \%$ dan $48,6 \%$. Pasien sebagian besar memiliki status oral hygiene yang tergolong buruk $(90,5 \%)$, dan $31,1 \%$ positif menderita oral candidiasis.

Karakteristik-karakteristik sampel penelitian tersebut kemudian dibedakan menurut ada tidaknya oral candidiasis, dengan hasil seperti ditunjukkan pada Tabel 2.

Oral candidiasis pada pasien laki-laki $(18,9 \%)$ relatif hampir sama dengan yang ditemukan pada perempuan $(12,2 \%)$. Uji chi square menghasilkan nilai $p=0,168(p>0,05)$ menunjukkan tidak ada perbedaan kejadian oral candidiasis menurut jenis kelamin. Menurut kelompok umur, juga tidak ada perbedaan kejadian oral candidiasis antara pasien yang berumur $\leq 45$ tahun dan $>45$ tahun $(13,5 \%$ dan $17,6 \%$ ) dengan nilai $p$ dari uji chi square sebesar 0,363 ( $p>0,05)$.

Berdasarkan status oral hygiene, oral candidiasis pada oral hygiene buruk $(29,7 \%)$ jauh lebih banyak daripada oral candidiasis pada oral hygiene sedang (1,4\%). Namun hal ini juga berlaku untuk pasien yang tidak terkena oral candidiasis, pada oral hygiene buruk sebanyak $60,8 \%$ sedangkan pada oral hygiene sedang sebanyak $8,1 \%$. Hasil uji 
korelasi kendall tau diperoleh nilai $p$ sebesar $0,235$ ( $p>0,05)$ menunjukkan tidak ada hubungan antara oral hygiene dengan oral candidiasis.

\section{DISKUSI}

Oral Candidiasis merupakan infeksi pada mukosa mulut yang disebabkan Candida spp. yang menjadi patogen. ${ }^{1}$ Candida spp. merupakan salah satu infeksi nosokomial yang paling sering muncul di seluruh dunia dengan angka morbiditas, mortalitas yang tinggi. Candida spp. adalah anggota flora normal terutama saluran pencernaan, selaput mukosa rongga mulut, vagina, uretra, kulit. Ditempattempat ini jamur dapat menjadi dominan dan menyebabkan keadaan-keadaan patologik ketika daya tahan tubuh menurun baik secara lokal maupun sistemik. ${ }^{2}$

Mekanisme terjadinya oral candidiasis terjadi melalui transmisi patogen dari species candida melalui jalur endogen dan eksogen. ${ }^{5}$ Untuk jalur endogen dimana spesies candida itu terdapat microbiota dari letak anatomi yang bervariasi dan terjadinya kondisi host yang lemah berpeluang terjadinya patogenitas. Untuk mekanisme jalur eksogen dapat terjadi melalui tangan dari tenaga kesehatan yang merawat pasien dimana kurang terjaga kebersihannya sehingga apabila tenaga medis tersebut tidak cuci tangan atau menjaga kebersihannya setelah menangani pasien yang satu ke pasien yang lain dapat menimbulkan terjadinya patogenitas. Infeksi juga bisa berasal dari kontaminasi pemasangan kateter dan intravena. ${ }^{6}$

Faktor predisposisi kondisi sistemik dan lokal mempengaruhi kerentanan dan gangguan sistem imun sehingga terjadi peningkatan proliferasi, kolonisasi dan adhesi Candida $s p$. di rongga mulut, yang mengakibatkan keseimbangan flora normal terganggu dan terjadi infeksi dan invasi Candida sp. Faktor predisposisi meliputi faktor sistemik seperti kondisi supresi imun, keganasan, gangguan endokrin, defisiensi nutrisi, medikasi dan faktor lokal yaitu perubahan saliva, diet tinggi karbohidrat, penggunaan protesa dental, merokok, dan kebersihan mulut yang buruk. ${ }^{7}$

Keberadaan Candida dalam rongga mulut terjadi melalui beberapa tahapan yaitu akuisisi Candida dari lingkungan, stabilitas pertumbuhan, perlekatan dan penetrasi Candida dalam jaringan. Tahap akuisisi adalah masuknya sel jamur ke dalam rongga mulut. Umumnya terjadi melalui minuman dan makanan yang terkontaminasi oleh Candida. Dalam rongga mulut dengan kolonisasi, Candida dapat ditemukan dalam saliva dengan konsentrasi 300-500 sel/ml. Candida dalam saliva menjadikan saliva dapat berperan sebagai media transmisi. ${ }^{8}$

Tahap stabilitas pertumbuhan adalah keadaan ketika Candida yang telah masuk melalui akuisisi dapat menetap, berkembang, dan membentuk populasi dalam rongga mulut. Hal itu berkaitan erat dengan interaksi antara sel jamur dengan sel epitel rongga mulut hospes. Pergerakan saliva yang terjadi secara terus menerus mengakibatkan sel Candida tertelan bersama saliva dan keluar dari dalam rongga mulut. Jika penghilangan lebih besar dari akuisisi maka tidak terjadi kolonisasi. Jika penghilangan sama banyak dengan akuisisi maka agar terjadi kolonisasi diperlukan faktor predisposisi. Jika penghilangan lebih kecil dari pada akuisisi maka Candida akan melekat dan bereplikasi. Hal itu yang merupakan bagian penting kolonisasi yang merupakan awal 
terjadinya infeksi. $^{9}$

Adhesi adalah interaksi antara sel Candida dengan sel penjamu yang merupakan syarat terjadinya kolonisasi. Interaksi antara Candida dengan hospes dapat terjadi dengan sel epitel, sel endotel dan sel fagosit. Kemampuan melekat pada sel inang merupakan tahap penting dalam kolonisasi dan penetrasi (invasi) ke dalam sel inang. Bagian pertama Candida yang berinteraksi dengan sel inang adalah dinding sel. ${ }^{10}$

Dinding sel Candida tersusun atas enam lapisan. Lapisan paling luar adalah fibrillar layer, kemudian mannoprotein, ß-glucan, ß-glucanchitin, mannoprotein dan membran plasma. Dinding sel terdiri atas karbohidrat $80-90 \%$, protein $6-25 \%$ dan lipid $1-7 \%$. Struktur dinding sel bertanggung jawab untuk melindungi sel ragi dari lingkungan yang tidak menguntungkan dan rigiditas yang memberikan bentuk khas yang merupakan karakteristik jamur. Interaksi dapat terjadi secara spesifik maupun nonspesifik. Interaksi spesifik berhubungan dengan adhesi pada permukaan epitel yang kemudian menyebabkan invasi Candida ke berbagai jenis permukaan jaringan. Interaksi non-spesifik meliputi hidrofobik dan kekuatan elektrostatik. ${ }^{11}$

Pada penelitian yang dilakukan oleh Fanello yang dikutip dari Journal of Medical Microbiology dilakukan survei mengenai kolonisasi atau infeksi jamur terhadap 256 pasien rawat inap. Dari 35 pasien yang terinfeksi, 57\% menderita oral candidiasis, dimana faktor resiko utama penyebab kolonisasi adalah protesa gigi, kebersihan mulut yang buruk dan penggunaan antibiotik. Penelitian tersebut menunjukkan hubungan yang signifikan antara kolonisasi oral terhadap timbulnya infeksi jamur pada pasien rawat inap. ${ }^{12}$
Hasil Penelitian ini menunjukkan status oral hygiene pada pasien rawat inap yang dirawat di Rumah Sakit Islam Sultan Agung Semarang dalam penelitian ini sebagian besar berada pada kategori buruk (90,5\%). Oral candidiasis pada pasien rawat inap dalam penelitian ini sebanyak $31,1 \%$. Oral candidiasis ditemukan pada 22 pasien dengan oral hygiene buruk dari $(95,7 \%)$, sedangkan yang ditemukan pada pasien dengan oral hygiene sedang sebanyak $4,3 \%$. Temuan ini hampir mendekati temuan pada penelitian Muzurovic bahwa pasien yang dirawat di Institusi Medis Sarajevo dengan oral hygiene buruk semuanya $(100 \%)$ terpapar spesies Candida.13 Spesies Candida muncul sebagai organisme komensal dalam orofarink dan karena beberapa gangguan sistemik maupun lokal jumlah Candida tersebut meningkat jumlahnya dan invasif sehingga menyebabkan kerusakan mukosa oral. Infeksi spesies Candida pada lingkungan oral inilah yang disebut dengan oral candidiasis. ${ }^{13}$

Pada penelitian ini secara perhitungan statistik tidak ditemukan hubungan oral hygiene buruk dengan terjadinya oral candidiasis. Pada penelitian pasien dengan oral hygiene buruk yang tidak menderita oral candidiasis juga lebih banyak yaitu 88,2\% (45 dari 51 pasien) daripada pasien dengan oral hygiene sedang $(11,8 \%)$. Oral hygiene yang buruk tidak berhubungan langsung dengan oral candidiasis akan tetapi melalui ada tidaknya kolonisasi oral. Temuan penelitian Fanello pada tahun 2011 menunjukkan terdapat hubungan antara kolonisasi oral candidiasis dengan onset dari infeksi jamur candida,dan dari 35 pasien yang terinfeksi $57 \%$ diantaranya menderita oral candidiasis. ${ }^{12}$ Dari penelitian terdahulu dapat disimpulkan adanya peran penting jamur dalam terjadinya infeksi nosokomial. ${ }^{12}$ Faktor- 
faktor risiko utama dari kolonisasi oral candida selain oral hygiene yang buruk diantaranya adalah protesa gigi tiruan dan penggunaan antibiotik. Faktor risiko infeksi selain yang telah disebutkan untuk kolonisasi oral adalah penyakit endokrin, status gizi buruk, lama rawat inap dan hitung koloni candida yang tinggi. ${ }^{12}$

Penelitian ini menyimpulkan tidak terdapat hubungan antara Oral Hygiene buruk dengan pertumbuhan OralCandidiasisyang merupakan indikator adanya infeksi nosokomial.

\section{DAFTAR PUSTAKA}

1. Akpan A, Morgan R. Oral Candidiasis. Postgrad MedJ. 2002; 78: 455-59.

2. Brooks G.F., Carrol K.C., Butel J.S., Morse S.A. Medical Microbiology. 24thed. Mc Graw Hill; 2007. 642-5 p

3. Kathryn Salamone, Elaine Yacoub, Anne Marie Mahoney, Karen-leigh Edward. Oral Care of Hospitalised Older Patients in the Acute Medical Setting. J Natl Cent Biotechnol Inf. 2013; 80(8): 1-6.

4. Clark, J.M. Nursing in community. Conecticut: Appleton \& Launge, Prectice Hall. 2003. 234-41 p.

5. Colombo, A. L, \& Guimaraes, T. Epidemiology of hematogenous infections due to Candida spp. Rev Soc Bras Med Trop. 2003; 36:599-607.
6. Ingham, C. J., Boonstra, S., Levels, S., de Lange, M., Meis, J.F. \& Schneeberger, P. M. Rapid susceptibility testing and microcolony analysis of Candida spp. cultured and imaged on porous alumunium oxide. PloS ONE 7. 2012; e33818.

7. Scully C. Oral and Maxillofacial Medicine. Edinburgh: Wright; 2004:252-68

8. Richard D, Cannon MA, Chaffin WJ. Colonization is crucial factor in oral candidiasis. J Dent Educ 2001; 65(8):785-8.

9. Hannula J. Clonal types of oral yeasts in relation to age, health and geography (dissertasi). Finland. Institute of Dentistry, Departement of Periodontology, University of Helsinki. 2000.

10. Kusumaningtyas E. Mekanisme infeksi Candida albicans. Lokakarya nasional penyakit zoonosis. 2007:304-16.

11. Hendriques MCR. Candida dubliniensis versus C.albicans adhesion and biofilm formation Department of biological engineering (dissertation) University of Minho Departement of Biological engirecly. 2007.

12. S. Fanello., J.P Bouchara., M. Sauteron., V. Delbos. E. Parot., A. Marot-Leblond., E. Moalic., A.M. Le Flohicc., B. Brangerd. Predictive Value of Oral Colonization by Candida yeasts dor the onset of a nosocomial infection in elderly hospitalized patients. J Med Microbiol. 2006; 55:223.

13. Muzurovic S., Babajic E., Masic T., Smajic R., Selmanagic A. (2012). The relationship between oral hygiene and oral colonisation with candida species. Med Arth. 2012 Dec; 66(6): 415-417. 